\title{
SERVICE DELIVERY PROTESTS, STRUGGLE FOR RIGHTS AND THE FAILURE OF LOCAL DEMOCRACY IN SOUTH AFRICA AND UGANDA: PARALLELS AND DIVERGENCES
}

\author{
Christopher MBAZIRA*
}

\begin{abstract}
Although the two countries are thousands of miles apart, Uganda and South Africa have both experienced service delivery protests in recent years. The protests have been directed mainly at local governments, although in Uganda some are directed at private service providers such as the electricity distributor, Umeme. There are a number of parallels and divergences between the two countries, particularly in relation to the causes and the nature that the protests have taken. Both countries are experiencing challenges in implementing decentralisation, which has mainly been characterised by a failure to effectively involve local communities in decision-making as a way of effecting local democracy. Mismanagement, corruption, and incapacity to deliver at the local levels are common to both countries. The divergences relate mainly to the level of organisation, frequency and magnitude of the protests. The local government legal framework of Uganda does not emphasise service delivery as much as the South African legal framework does. There is an urgent need for both countries to make local democracy work by building civic competence and creating operational and effective structures for civic participation in local affairs.
\end{abstract}

Keywords: local government

\section{INTRODUCTION}

In spite of the differences in economic development, Uganda and South Africa are both facing challenges as regards service delivery at local levels. As a result, both countries have in recent years been hit by service delivery protests. While the magnitude, levels of organisation and intensity of the protests may differ, with the South African protests being bigger in intensity and frequency, there are some common factors that define the occurrence of the protests. Historically, albeit with different contexts, both countries have histories of draconian and authoritarian rule. In the 1990s, both countries were

Bram Fischer Fellow (July to August 2012) and Visiting Associate Professor, Oliver Schreiner School of Law, University of Witwatersrand; Associate Professor \& Coordinator, Public Interest Law Clinic, School of Law, Makerere University. The comments of the anonymous reviewers are acknowledged, in addition to the comments of the participants at the Seminar on Local Service Delivery Protests in Uganda and South Africa on 7 August 2012 held at the School of Law, University of Witwatersrand, Johannesburg. Special acknowledgement is made of Jackie Dugard for her comments on the original paper on which this article is based. 
viewed as 'the new generation of African states that are seen as turning their back on decades of authoritarian rule, instead embracing open government'. Additionally, both countries embraced decentralisation and committed to the devolution of powers and democratic participation at the local level. ${ }^{2}$ Unfortunately, however, both countries have not attained well-managed local governments and efficient service delivery as was anticipated; there are problems of local accountability and lack of adequate resources to perform the functions devolved. ${ }^{3}$

Similarly, both countries adopted policies that pushed for restructuring and privatisation of public enterprises and services. In the case of Uganda, privatisation was vigorously pursued as part of the Structural Adjustment Programmes (SAPs) embraced in the late 1980s. For South Africa, privatisation was pursued as part of the Growth, Employment and Distributive policy adopted in 1996. It is not within the scope of this article to discuss the successes and failures of privatisation in South Africa and Uganda. What needs to be noted though is that in both countries, privatisation has had an impact on the provision of public services. In some cases, services previously provided by government were devolved to private entities, while in other cases, government entities, including local governments, especially in South Africa, started pursuing policies of cost recovery and operated in a commercial manner. All this has had an impact on the delivery of some services arising mainly from tariff increments and strict methods of debt recovery. Yet, as is the case in many African countries that embraced privatisation, the benefits associated with privatisation such as higher profitability, improved performance and productivity have not been attained. ${ }^{6}$

In both countries, there has been a failure of local democracy, reflected in the increasing marginalisation of local communities, failure to be responsive to the needs of the poor and to effectively consider local voices in decisionmaking. This has vitiated one of the motivations of decentralisation, which is the promotion of better utilisation of resources for the needs of local communities. ${ }^{7}$ This though does not mean that those functions reserved

1 J Hearn 'Foreign Aid, Democratisation and Civil Society in Africa: A Study of South Africa, Ghana and Uganda' Institute for Development Studies Discussion Paper $368<\mathrm{http}: / /$ www.eldis. org/vfile/upload/1/document/0708/DOC6995.pdf $>2$.

2 CL Dauda 'Democracy and Decentralisation: Local Politics, Marginalisation and Political Accountability in Uganda and South Africa' (2006) 26 Public Administration and Development 291, 292.

3 FP Kulipossa 'Decentralisation and Democracy in Developing Countries: An Overview' (2004) 14 Development in Practice 769, 773.

4 See J Oloka-Onyango 'Poverty, Human Rights and the Quest for Sustainable Human Development in Structurally-Adjusted Uganda' (2000) 18 Netherlands Quarterly of Human Rights 23.

5 See J Afeikhena 'Privatisation and Regulation in South Africa: An Evaluation' (September 2004) National Institute for Economic Policy <http://www.competition-regulation.org.uk/conferences/ southafrica04/Afeikhena.pdf $>$.

6 Ibid 2.

7 N Devas \& U Grant 'Local Government Decision-making - Citizen Participation and Local Accountability: Some Evidence from Kenya and Uganda' (2003) 23 Public Administration and Development 307, 307. 
for the central governments are well-managed. In Uganda, for instance, mismanagement, under-funding and corruption characterise all central government institutions. ${ }^{8}$

It is against the above background that this article sets out to study the service delivery protests that Uganda and South Africa have experienced. The article draws parallels and divergences by showing that the factors that have influenced the protests in South Africa are not different from those in Uganda; and reflect the failure of local democracy in both countries. The divergences appear mainly in the magnitude, intensity and levels of organisation that the protests have taken, yet similarities include the fact that in both cases, at the frontlines of the violent protests has been unemployed youths.

The article is divided into three parts: The first part explores the subject of service delivery in the context of local government, analysing decentralisation trends in both countries and the relationship with service delivery. The first part also describes and analyses the causes and form which the service delivery protests have taken in both countries. The second part synthesises the parallels and divergences between causes and nature of the protests in the two countries. While the last part draws conclusions and makes some recommendations on how the pitfalls of local government that have resulted into the protests could be overcome.

\section{Service Delivery and the Local Government ConteXt}

One of the key features which define service delivery in many countries is decentralisation and the systems of local government. Decentralisation could be understood as the assignment of fiscal, political and administrative responsibilities by the central government to lower level governments, characterised by delegation and devolution. ${ }^{9}$ The motivation for decentralisation in Uganda and South Africa is not any different from that which has informed decentralisation the world-over. The argument is that decentralisation results in better use of resources by ensuring that resource use decisions will reflect the needs of the citizens at the local level. ${ }^{10}$ It is argued that partly because of the access to information about local conditions, which the centre may find hard to get, decentralised governments will have better knowledge of local preferences. This helps overcome the indifference usually associated with central government bureaucrats. ${ }^{11}$ Yet, in addition to resulting in plans that answer to the people's needs, decentralisation helps to enlist support for the implementation of plans since it creates a sense of

8 It is not within the scope of this article to address the deficiencies of the central government institutions responsible for the discharge of several functions related to service delivery. The scope of the article is defined to narrowly focus on local government.

9 J Litvack, J Ahmad \& R Bird 'Rethinking Decentralization in Developing Countries' (1998) The Int Bank of Reconstruction and Development 4.

10 Devas \& Grant (note 7 above) 307.

11 KR Hope 'Decentralisation and Local Governance Theory and the Practice in Botswana' (2000) 17 Development Southern Africa 519, 520. 
ownership. ${ }^{12}$ Decentralisation has also been viewed as a mechanism to disperse power; to ensure political stability; to bring representative governance closer to citizens; and to improve the accountability and responsiveness of local leaders. ${ }^{13}$ Central provision of services has also been perceived as ineffective because of the difficulties of coordinating large-scale activities. ${ }^{14}$

Although it is beyond the scope of this article to make a case for and against decentralisation, it is worthwhile to briefly explore some of the cons of decentralisation. It has been argued that decentralisation breeds inequality before the law by subjecting different localities to different regimes of regulation, yet all services and other standards should be the same for all citizens. ${ }^{15}$ The effective local utilisation of resources advantage has been contested on the grounds that in some cases a local jurisdiction may actually be subsidising its neighbours when residents use facilities without their local governments contributing to them in what has been called 'free rider. ${ }^{16}$ Additionally, local governments may not be able and equipped to handle inherently complex problems, which may require the superior skills of centralised administration. ${ }^{17}$ Decentralisation of policy formulation and implementation could also result in what has been described as 'net loss of political control', ${ }^{18}$ which could compromise the regulatory functions of the state.

At the same time, it is important to note that, in practice, most local government systems are designed in such a manner that local autonomy is exercised within the framework of standards set by national legislation and policy. Examples in the case of South Africa are policies that define minimum levels of services such as water, which all municipalities are under duty to implement.

Additionally, the democracy related advantages of decentralisation are based on the assumption that the local citizens will always have an influence on decisions made by their local governments. ${ }^{19}$ Evidence from many parts of the world however suggests that local authorities have largely failed to move beyond mere consultation to engaging the poor and taking into account their needs in decision-making. ${ }^{20}$ This is the major detraction that has derailed local democracy in Uganda. ${ }^{21}$

D Conyers 'Decentralization: The Latest Fashion in Development Administration?' (1983) 3 Public Administration and Development, 97, 100.

13 J Akin, P Hutchinson \& K Strumpf 'Decentralisation and Government Provision of Public Goods: The Public Health Sector in Uganda' (2005) 41 J of Development Studies 1417, 1418.

14 Ibid 1420.

15 MS De Vries 'The Rise and Fall of Decentralization: A Comparative Analysis of Arguments and Practices in European Countries’ (2000) 38 European J of Political Research 193, 199.

16 Ibid.

17 Ibid 199-200.

18 AB Whitford 'Decentralization and Political Control of the Bureaucracy' (2002) $14 J$ of Theoretical Politics 167.

19 Devas \& Grant (note 7 above) 307.

20 Ibid 309.

21 Devas \& Grant (note 7 above) 313. 
It is against this background that the decentralisation processes in Uganda and South Africa and their impact on service delivery should be understood. Some of the contestations of the perceived advantages of decentralisation may emerge from this exploration.

\section{(a) Uganda}

Decentralisation in Uganda dates back to the colonial state as used to hold together the different ethnic communities that were artificially amalgamated into a state. The system however disintegrated after independence with the adoption of the Republican Constitution in 1967, intended to build a strong unified central government to define the new state. The last blow to decentralisation aspirations came during the dictatorship of the Idi Amin government (1971 to 1979). However, in 1987 the new National Resistance Movement (NRM) government, sought to revive local governance. In 1993, the Local Government (Resistance Council) Statute, Act 15 of 1993, was adopted, devolving a number of powers to elected local councils. A more comprehensive legal framework came when a new Constitution was adopted in 1995. The Constitution announced that the state would be guided by the principle of decentralisation and devolution of governmental functions and powers to the people at appropriate levels where they can best manage and direct their own affairs. ${ }^{22}$ Among the constitutional local government principles is the principle of ensuring peoples' participation and democratic control in decision-making, in addition to ensuring the full realisation of democratic governance at all local levels. ${ }^{23}$

In terms of functions, the local governments exercise executive functions, defined legislative powers and, uniquely, some judicial powers. ${ }^{24}$ Unfortunately, however, the Constitution is silent on the obligations of local governments as regards the provision of services. Although one would have expected these obligations to be detailed in the Local Government Act, ${ }^{25}$ the principal local government legislation, this is not the case. Without any indication that there is an obligation to provide these, the different functions of local government that relate to the provision of services are only detailed in schedule 2 of the Act. Although there is use of the word 'services' in the body of the Act, this is immediately linked to the schedule; moreover the language used is not obligatory: 'a local government council shall within the area of its jurisdiction provide services as it deems fit ... ' ${ }^{26}$

The functions to be discharged by the districts relevant to social services include: medical and health services, other than those reserved for the central government; water services, which includes provision and maintenance of water supplies in liaison with the ministry responsible for natural resources;

Constitution of the Republic of Uganda objective II(iii).

Ibid art 176(2)(b)(c).

See Local Council Courts Act 2006.

'Laws of Uganda' (2000) Chapter $243<$ http://www.ulii.org/ug/legislation/consolidated-act/243>.

Local Government Act s 30(1)(b) (emphasis added). 
road services, which includes the construction, rehabilitation and maintenance of roads not under central government; aiding and supporting the establishment of schools, hospitals, libraries and homes of the aged, among others; providing and managing sporting and recreation facilities and programmes for informal education; and remedial social welfare programmes aimed at the alleviation of social distress.

The functions of urban councils include: street lighting, fire brigade services, clinics and dispensaries; public lavatories, public baths and swimming pools; sanitary services for the removal and disposal of night soil, rubbish, carcasses of dead animals and all kinds of refuse; water supplies outside the jurisdiction of National Water and Sewerage Corporation (NWSC); education services; and maintenance of roads outside the jurisdiction of the central government.

Local governments can levy, charge and collect fees and taxes, including rates, rents, royalties, stamp duties, personal graduated tax, and registration and licensing fees. ${ }^{27}$ In addition to the levies, fees and charges, local governments are entitled to grants from the central government drawn from the consolidated fund. The grants include unconditional, conditional and equalisation grants. ${ }^{28}$ In spite of the above sources of funding, the capacity of local governments to collect local taxes has been constrained by a number of factors, including the limited local tax base. In 2005, graduated tax, which was a head tax imposed on all working adults in the locality, was abolished, substantially reducing the finances of the local governments. Although graduated tax was the major source of income for these governments, it remained unpopular because of the obscure system of its assessment and the brutal manner in which it was collected by law enforcement agencies. ${ }^{29}$ As regards the grants, ' $[t]$ he transfer system has become very complex'; there are 'multiple grants each with its own conditions, often allowing local councils limited scope for choice in relation to local circumstances, ${ }^{30}$ Yet, in many cases, the grants are consumed by administrative and operational costs, including salaries, with little or none being used for service delivery. ${ }^{31}$ Additionally, as indicated by Nick Devas and Ursula Grant, ${ }^{32}$ there are problems of lack of transparency, corruption, rent seeking, and abuse of tender procedures. All these have minimised effective mobilisation and use of resources.

The ability of councils to hold meetings has also been constrained because of the absence of funds to pay the allowances of the councillors. This has resulted in councillors not being able to discharge their oversight functions. ${ }^{33}$ The resource crisis has been exacerbated by the unprincipled and spontaneous creation of districts, done by the ruling party as a form of gerrymandering and

29 P Francis \& R James 'Balancing Rural Poverty Reduction and Citizen Participation: The Contradictions of Uganda's Decentralization Program' (2003) 31 World Development 325, 330.

30 Devas \& Grant (note 7 above) 313.

31 Francis \& James (note 29 above) 332.

32 Devas \& Grant (note 7 above) 313.

33 Ibid 34. 
as a tool for political patronage. ${ }^{34}$ By 1994 , the country had only 44 districts, which increased to 55 in 2005 and now stand at over 111 and will increase to 136 with the recent announcement that 25 new districts would be created if approved by Parliament. ${ }^{35}$ Unfortunately, these districts have increased the administrative expenses at local government level and depleted resources that would otherwise have been expended on providing services.

Corruption and misappropriation of resources have also constrained the performance of local governments and their ability to deliver services. On many occasions, the Inspectorate of Government, the watch-dog which investigates corruption cases, has ranked districts as the most corrupt public institutions. ${ }^{36}$ Reports also indicate that many districts have flouted and abused the procurement procedures, by among others not following competitive bidding and ensuring proper documentation. ${ }^{37}$ In 2011, the Auditor General's Report indicated that in the Financial Year 2010/2011, goods and services worth over 24-billion shillings had been procured by local governments without following the procurement laws and guidelines. ${ }^{38}$

The most important inefficiency has been the failure to achieve effective local participation in decision-making. On paper, the district planning process is supposed to be bottom-up, with every village preparing a Community Action Plan (CAP), which feeds into the parish CAP, through to the sub-county and ultimately the district plan, only finalised after a participatory budget conference. The practice is however different; CAP processes do not take place in many villages and parishes; and when this happens, the plans never make their way up. ${ }^{39}$ Although in some districts budget planning meetings are convened, the attendance is usually sporadic, mainly due to inadequate dissemination of information on the process. Yet, even where the processes have been implemented consistently, community members consulted do not see their suggestions on priority areas implemented. ${ }^{40}$ Additionally, the failure of most local councils to convene meetings has constrained their ability to influence decisions at the local levels. This has left critical policy decisions in the hands of bureaucrats, yet these are not as directly accountable to the people as the elected representatives.

It should also be noted that the central government has failed to relinquish much of the powers needed by the local governments in line with the policy

See E Green 'District Creation and Decentralisation in Uganda' (2008) Development Studies Institute, London School of Economics Working Paper Series 2.

35 '25 More Districts Created' New Vision (19 July 2012).

36 Y Mugerwa 'Uganda: Districts Remain Most Corrupt Bodies' The Monitor (16 June 2008) $<$ http://allafrica com/stories/200806160911 html $>$.

37 Inspectorate of Government 'Second Annual Report on Corruption Trends in Uganda: Using the Date Tracking Mechanism' (November 2011) <http://www.igg.go.ug/static/files/publications/ doc.pdf $>38$.

38 Office of the Auditor General Annual Report of the Auditor General for the Year Ended 30th June 2011 Volume 1, Performance Report 13.

39 Francis \& James (note 29 above) 331.

40 L Nyirinkindi 'Economic and Social Rights, Service Delivery and Local Government in Uganda' (2007) HURIPEC Working Paper 13, 23. 
on decentralisation. Instead, various line ministries have continued to implement various programmes at the local levels, albeit in an uncoordinated manner. The ministries have failed to integrate the various local government structures, including the planning committees, into their programmes. It has been argued that quality time, which should be spent by local governments on service delivery, is instead spent responding to the plethora of uncoordinated supervision and accountability processes required by the various ministries. ${ }^{41}$

The leadership problems that local governments are facing could also be related to the leadership challenges the country as a whole is facing. There is a gradual loss of confidence in the state, arising mainly from corruption, unresponsiveness and sometimes arrogance of state officials. More broadly, loss of confidence in the state is attributed to the manner in which the state has been managed. ${ }^{42}$

On ascending to power in 1986, the National Resistance Movement (NRM) failed to build political institutions that enjoyed a wide degree of political acceptability among different socio-political groups. ${ }^{43}$ Indeed, state sovereignty did not lie with legal institutions; instead, it laid with the NRM's political organs such as the NRM Secretariat, the Army High Command and the Army Council. $^{44}$ Although the first elections organised in 1989 were celebrated as having advanced democracy in a country that had been under dictatorial rule for over two decades, ${ }^{45}$ the elections were faulted. One of the major flaws was the demonstration by the NRM that it would not tolerate elections contested on a competitive political party basis, an approach that threatened its hold on power. ${ }^{46}$ This marked the birth of 'the movement' political system, a euphemistic expression of one-party rule, which the NRM argued was an all inclusive system that avoided the pitfalls of the multi-party system which had divided Uganda along ethnic and religious lines and resulted in conflict. ${ }^{47}$

Although the year 2005 saw reversion to the multi-party system, the 'no-party' movement system's culture has remained firmly rooted within several institutions of the state and has stifled smooth operation of the multiparty system. ${ }^{48}$ This has alienated those with divergent political views, both politicians and ordinary citizens, and is gradually pushing people to oppose the government in the face of increasing levels of poverty and inefficient/ non-service delivery.

$41 \quad$ Ibid 18.

42 W Muhumuza 'From Fundamental Change to No Change: The NRM and Democratization in Uganda' 41 Les Cahiers D'Afrique De L'est 21, 22.

43 D Mudoola 'Institutional Building: The Case of the NRM and the Military in Uganda 1986-9' in HB Hansen \& M Twaddle (eds) Changing Uganda The Dilemma of Structural Adjustment and Revolutionary Change (Eastern African Studies) (1991) 230, 231.

44 Ibid 235.

45 N Kafir 'The Uganda Elections of 1989: Power, Popularism and Democratization' in Hansen \& Twaddle (note 43 above) 247, 249.

46 Ibid 252.

47 C Mbazira 'Constructing a New Dawn? Assessing Democracy and Multi-part Politics in NRM's Uganda (2005 - 2011)’ (2011) HURIPEC Working Paper 33, 11.

48 Ibid 28. 
The loss of confidence is also linked to recent electoral flaws including intimidation of voters and candidates, militarization of the processes, vote buying, disenfranchisement, rigging and ballot box stuffing. Additionally, the Electoral Commission has failed to exude impartiality and remains appointed by the President. Although the appointment requires parliamentary approval, Parliament has largely remained a rubber-stamping institution. ${ }^{49}$

It is against the above context, characterised among others by the failure to meaningfully engage the local citizens, that the service delivery protests in Uganda should be understood.

\section{(i) The protests in Uganda}

Different from South Africa, there has not been any serious study on the nature and form that service delivery protests have taken in Uganda. The descriptions in this section are based on scanty media reports and on the author's own observations. It should be noted from the onset that the service delivery protests in Uganda have not been as massive, drawn-out and well organised as those in South Africa. Nonetheless, the media on a daily basis carries reports of residents protesting against poor or non-delivery of services. In some cases, the protests have been directed not necessarily at government structures, but at service providing corporations. This includes the NWSC, a government corporation responsible for processing and distributing water, and Umeme, an electricity distributor and a subsidiary of South Africa's Eskom. The protests directed at local government officials have mainly been those related to poor roads, either due to non-maintenance or delayed/abandoned rehabilitations, which have unreasonably inconvenienced residents. One such protest happened in August 2009, when residents of a village called Busabala accosted the Wakiso District chairperson, lured him to a dusty road with many potholes, made him sit down surrounded by a mob, and sprayed him with dust, pouring some in his posh vehicle while shouting that he should also feel the dust like them. ${ }^{50}$ In another case, residents of Rwamagwa in Rakai District planted banana stems in the middle of a gravel road, stating that because of the road's poor state, it was no-longer useful as a road, but as a garden. ${ }^{51}$

There have also been dramatic protests over the poor state of healthcare services. In October 2011, a man undressed in protest at a government health centre where he had taken a boy for treatment, but was asked to provide medical supplies. The man was later joined by other residents and local politicians in support of the protest. ${ }^{52}$ In another incident, in February 2011, patients in the

See C Mbazira 'Reform Long Overdue: A Comparative Analysis of Improvements Necessary to Electoral Laws, Processes and Institutions In Uganda' (2009) HURIPEC Working Paper 26.

50 See J Lule 'Kyeyune won't Penalise Attackers' New Vision (5 August 2009) < http://www. newvision.co.ug/D/8/13/690394>.

51 See 'Residents in Rwamagwa Protest over Bad Roads' (11 November 2011) <http://www.ugpulse. com/uganda-news/government/residents-in-rwamagwa-protest-over-bad-roads/22709.aspx $>$.

52 'Uganda: Man Strips Naked in Protest of Poor Health Services' (10 May 2011) < http://www.nl-aid. $\mathrm{org} /$ continent/sub-saharan-africa/uganda-man-strips-naked-in-protest-of-poor-health-service $>$. 
orthopaedic ward at Mulago Hospital, the oldest and biggest national referral hospital, protested about the lack of services by parading their beds outside the ward. It later emerged that a number of them had actually paid bribes to doctors to get services, but had still not been attended to. ${ }^{53}$ Another protest in this sector was by patients in an Ebola isolation ward in Kagadi hospital. Uganda was in July 2012 attacked by the Ebola virus, a deadly contagious virus with no known cure. To contain the spread of the virus, isolation wards were set up in areas hit by the virus. By the beginning of August 2012, there was evidence that government was not taking good care of the patients in the isolation wards. On 2 August 2012, this forced patients at Kagadi Hospital isolation ward to protest by walking out of the ward demanding food and medical attention. Medical staff not wearing protective gear fled as the patients walked out of the ward. The situation was only controlled by the Deputy Resident District Commissioner who, dressed in protective gear, talked down the patients. ${ }^{54}$ Three days later, residents of Jinja protested at the maternity ward of the Jinja Referral Hospital after the death of an expectant mother. The mother had been neglected after her relatives failed to raise a bribe of approximately US $\$ 400$ demanded by medical staff before they would carry out surgery on her. By the time they raised half of the money, it was too late, the mother died on the operating table. Residents stormed the hospital demanding the arrest of the gynaecologists who had demanded the bribe. ${ }^{55}$

The electricity related protests have resulted either from continuous load-shedding, increased tariffs or failure to attend to technical problems resulting into black-outs. ${ }^{56}$ Other electricity related mishaps that have spurred resentment of Umeme include poor billing, poor monitoring of services in some cases leading to death, significant increment of tariffs yet for poorly managed services and non-responsiveness to customer needs. In one village called Nakaseke, residents ran out of patience when a broken transformer had not been repaired a month after it broke down. The residents protested by stoning electricity poles and blockading roads. A few days later a new transformer was delivered by Umeme. ${ }^{57}$

In some cases, the protests have been led by politicians, especially members of Parliament, who are always eager to demonstrate that they care about the needs of their people. ${ }^{58}$ Although the demographics of the protests depend on the community, at the frontlines of the protests, especially those characterised by violence, have mainly been unemployed youths. At the moment, Uganda

56 See 'New Power Tariffs: Gayaza Residents Demonstrate' (17 January 2012) <http:// ugandaradionetwork.com/a/story.php?s=39702>.

57 See 'Umeme Restores Power in Nakaseke' (17 November 2011) <http://ugandaradionetwork. com/a/story.php?s=38445>.

58 See for instance 'MP to Mobilise Protest Over Road' The Monitor (29 March 2007) <http://www. accessmylibrary com/article-1G1-161232650/mp-mobilise-protest-over.html>; and S Arinaitwe 'Lukyamuzi Protests Bad Roads' Daily Monitor (24 July 2012) <http://www.monitor.co.ug/ News/National/Lukyamuzi+protests+bad+roads/-/688334/1461610/-/186pll/-/index.html>. 
has the youngest population in the world, with over 70 per cent of the country's population being under the age of 30 years. ${ }^{59}$ Unfortunately, a large number of youths are unemployed and roam the streets in search of a livelihood. By 2007, it was estimated that youth unemployment stood at 22 per cent, and even higher among youth with university degrees and those in rural areas. ${ }^{60} \mathrm{Such}$ large numbers of unemployed youths living in poverty have not just been easy targets for those organising protests, but have spontaneously been attracted to avenues through which to vent their frustration at a government that has not met their needs.

Another factor to which the increasing levels of service delivery protests and the violence could be attributed to is the breakdown of the Rule of Law. The breakdown in the Rule of Law is explained by the inefficiency of law, justice and order institutions, due to corruption and mal-administration. This has resulted in people increasingly taking the law into their hands, in many cases through mob-justice. There have been many cases of people attacking police stations and demanding the release of suspects so that they are dealt with by the mobs rather than the corrupt and inefficient police. ${ }^{61}$ This approach has been extended to service delivery structures; in the face of unresponsiveness, many residents have chosen violence as a solution. In some cases, as seen in one of the electricity cases described above, this approach has actually worked, with services being delivered to quell the violence. A few weeks after spraying the Wakiso District chairperson with dust, work on the Busabala road began. In the days after the incident, one of the country's newspapers carried a story in which it was stated ' $[\mathrm{w}]$ hat the people did was akin to mob justice, and it would appear that if this trend continues, more of our leaders will dance to the same unpleasant melodies'. ${ }^{62}$

The country has been characterised by electoral related protests, mainly arising from mismanagement and irregular elections, at least in perception. Recently, the electoral anarchy came to the fore in the 2011 presidential and parliamentary elections. The elections were characterised by massive voter bribery and disenfranchisement of voters, especially in areas believed to support the opposition. In April 2011, inspired by the Arab spring, opposition politicians rejected the results, which gave the NRM victory, and mobilised people to take to the streets in what was described as 'walk-to-work'. The election fracas coincided with rising costs of living because of a high inflation rate believed to have resulted from vote buying, combined with the sudden rise in fuel prices. Hordes of people demonstrated by walking to work; police confronted the demonstrators with brute force. Although they have since subsided in intensity, opposition protests have continued and have also Country Case Study (2010) <http://populationaction.org/wp-content/uploads/2011/12/SOTC Uganda_CCS.pdf $>5$.

60 Ibid 8.

61 See F Jjuuko 'Law and Access to Justice' <http://www kituochakatiba.org/index2. php?option $=$ com_docman\&task $=$ doc_view\&gid=203\&Itemid $=27>$.

62 See 'Stand Warned; People are Waking up to their Rights' The Observer (31 August 2009). 
inspired service delivery related protests. Gradually, a culture is building to the effect that people must demonstrate, sometimes violently, in order for their voices to be heard.

\section{(b) South Africa}

As part of the transition from apartheid to democracy, the African National Congress (ANC) focused on transforming local government by moving away from the racially designed and discriminatory local government structures to democratically elected non-racial local governments. One of the immediate aims was to achieve the amalgamation of formerly white areas with the black townships and informal settlements under a unitary administrative control. ${ }^{63}$

The transformation of local government started with a transitional legislative regime, which largely focused on amalgamation. This was followed with a permanent legal framework. According to the Constitution of the Republic of South Africa, 1996, South Africa comprises the national, provincial and local spheres of government, which are distinct, interdependent and interrelated. ${ }^{64}$ The 'local sphere of government' is defined in Chapter 7 to consist of municipalities. ${ }^{65}$ The objects of local government are defined to include: providing democratic and accountable government for local communities; ensuring provision of services to communities in a suitable manner; promoting social and economic development; promoting a safe and healthy environment; and encouraging the involvement of communities and community organisations in matters of local government. ${ }^{66}$

The Constitution is also instrumental in as far as it defines the functions of the different spheres of government as detailed in schedules 4 and 5. It is on the basis of this that budgeting is done, resources are mobilised, and obligations understood, especially as they relate to the realisation of the economic and social rights guaranteed in the Bill of Rights.

One issue of concern is that of 'unfunded mandates'. This has been defined as arising from a situation where a branch of government performs functions outside its prescribed functions and for which it has no funding. ${ }^{67}$ Besides shrinking the policy making space of local governments, ${ }^{68}$ unfunded mandates have the potential of eating into local resources that could have been used for pre-determined services, thereby affecting access to the latter. Although there are some guarantees in the law against the negative effects of unfunded

See C Pycrof 'Democracy and Delivery: The Rationalization of Local Government in South Africa' (2000) 66 Int Review of Administrative Sciences 143, 145.

64 Constitution s 40.

65 Ibid s 151(1).

66 Ibid s 152(1).

67 Financial and Fiscal Commission 'The Impact of Unfunded Mandates in South African Intergovernmental Relations' (2011) 3 Policy Brief 2.

68 See N Steytler, J de Visser \& R Williams 'Unfunded Mandates: Directing Subnational Governments' Paper presented at the Annual Conference of the International Association of Centers for Federal Studies, Speyer(1 October 2011)<http://www.foev-speyer.de/veranstaltungen/ IACFS/Steytler\%20De\%20Visser\%20and\%20Williams\%20-\%20unfunded $\% 20$ mandates.pdf $>$. 
mandates in the form of following through with a consultation process as enumerated in ss 9 and 10 of the Municipal Systems Act 32 of 2000, it is not certain that the interests of local governments will always be considered. ${ }^{69}$ In addition to eating into resources as indicated above, this has resulted in the diversion of the attention of local governments, with their limited capacity, to function outside their mandates, thereby indirectly affecting their capacity to deliver services.

The law most relevant to municipalities in relation to service delivery is the Municipal Systems Act. This law was promulgated among others to establish core principles, mechanisms and processes that are necessary to enable municipalities to move progressively towards the social and economic development of local communities. This is in addition to ensuring universal access to services that are affordable. ${ }^{70}$ The Act is also intended to establish mechanisms that empower the poor and ensure that municipalities put in place service tariffs and credit control policies that take the needs of the poor into account. $^{71}$

The Municipal Systems Act defines the rights of the community to include the following: contributing to the decision-making processes of the municipality; to be informed of decisions made; to use and enjoy public facilities; and to have access to municipal services, subject to certain duties, which includes payment of fees where applicable. ${ }^{72}$ Correspondingly, the municipalities have a wide range of duties, which include: being responsive to the needs of the local community; facilitating the culture of public service and accountability by staff of local government; and giving communities full and accurate information about the level and standard of services they are entitled to. ${ }^{73}$ Some of the above rights and duties are defined with more detail in chapters of the Act. Chapter 8, for instance, is dedicated to the subject of services, defining the duties of the municipalities to include giving priority to the basic needs of the community and ensuring that all members of the community have access to at least the minimum levels of basic municipal services. ${ }^{74}$ While requiring municipal services to be equitable and accessible, the Act requires the services to be provided in a manner that is conducive to the prudent, economic, efficient and effective use of available resources. This is in addition to ensuring that the services are financially sustainable. ${ }^{75}$ The Act also defines principles to guide municipal tariff policies, which are among others things, intended to address the needs of poor households. Poor households are supposed to have access to at least basic services, either 
through tariffs that cover only operating costs, through special or life line tariffs, or through direct and indirect subsidisation. ${ }^{76}$

It should be noted that although the legal mandate of local governments in South Africa is clearly defined as seen in the legal framework, the system of local governance has faced some challenges. In many respects, the system of local government is a manifestation of 'government failure', which is the inability of government to achieve its intended outcomes. ${ }^{77}$ With regard to service delivery, local government failure in South Africa is broadly associated with the limitations of South Africa's macro-economic model, which has failed to advance inclusive economic and human development. ${ }^{78}$ It has been illustrated that under this model, municipalities are under considerable financial pressure to limit services to households that cannot pay for them, as the income derived from water, electricity and sanitation services is the most important source of revenue for local government. ${ }^{79}$ In addition to the impact of this economic model, local government failure, as is illustrated below, has been the failure to effectively utilise spaces for public participation in the decision-making process and empowering communities to influence outcomes in line with their needs. These failures have largely been responsible for the wave of service delivery protests that have rocked the country. The failures are explained below and in relation to the service delivery protests.

The government is cognisant of the challenges that the local government system is facing. In 2009, the Department of Cooperative Governance and Traditional Affairs adopted what it described as the Local Government Turnaround Strategy. In this strategy, government acknowledges the fact that local governments are not working as effectively as they should because of a number of problems linked to: systemic factors; policy and legislative factors; political factors, capacity and skills constraints; weak inter-governmental support and oversight; and inter-governmental fiscal system issues. ${ }^{80}$ One of the bases of the strategy is what is described as the objectives of an ideal local government, which include: providing democratic and accountable government for local communities; being responsive to the needs of the local community; ensuring the provision of services to communities in a sustainable manner; promoting social and economic development; promoting a safe and healthy environment; encouraging the involvement of communities and community organisations in the matters of local government; facilitating a culture of public service and accountability amongst its staff; and assigning clear

76 Ibid s 74(2)(c).

77 A Buthelezi \& B Dollery 'An Exploratory Analysis of Local Government Failure in South Africa' (2004) 28 Studies in Economics and Econometrics 91, 92.

78 J Dugard 'Urban Basic Services in South Africa: Rights, Reality and Resistance' in M Langford et al (eds) Symbols or Substance The Role and Impact of Socio-Economic Rights Strategies in South Africa [Forthcoming] 1. See also P Bond 'South Africa's Bubble Meets Boiling Urban Social Protest' (2010) 62 Monthly Review <http://monthlyreview.org/2010/06/01/bond>.

79 Dugard (note 78 above) 2.

80 Department of Cooperative Government and Traditional Affairs Local Government Turn Around Strategy 3 . 
responsibilities for the management and coordination of the administrative units and mechanisms. ${ }^{81}$

It is on the basis of the above that the Turnaround Strategy sets out what needs to be done to tackle the problems that municipalities are facing. This includes: ensuring that municipalities meet the basic service needs of communities; building a clean, effective, efficient, responsive and accountable local government; improving performance and professionalism in municipalities; improving national and provincial policy, oversight and support; and strengthening partnerships between local government, communities and civil society. Unfortunately, many targets set by the strategy have not been realised, among others due to the failure of government to commit resources to the implementation of the strategy. ${ }^{82}$ With the increasing numbers of service delivery protests, it is clear that the strategy is yet to tackle the service delivery factors that result into protests.

\section{(i) The protests in South Africa}

Although South Africa has had a history of protests, inspired by strong social movements, the service delivery protests that have rocked the country in recent years are unprecedented. In August 2005, residents of Khutsong township in the Free State protested over service delivery and municipal demarcations by burning and looting shops, disrupting schools, damaging property, and blockading roads. ${ }^{83}$ The Khutsong protests were followed with countrywide protests that bust out like popcorn. The protests have been characterised by mass meetings, drafting memoranda, petitions, 'toyitoying, ${ }^{84}$ processions, stayaways, election boycotts, blockading of roads, construction of barricades, burning of tyres, looting, destruction of buildings, chasing unpopular individuals from townships, and confrontations with the police. ${ }^{85}$ What has also characterised the South African protests is that while they appear spontaneous, many of them are usually well organised and normally planned at open public meetings. Although sometimes sparked off by spontaneous events such as the failure to provide prize money at a sports event in Voortrekker in 2009, they are mostly caused by deep discontent with the level of service delivery and the ineffectiveness of the available channels of participatory democracy. ${ }^{86}$

81 Ibid 5.

82 See J Mettler 'Local Government Turnaround Strategy - Constraints and Successes' Paper presented at the Institute for Municipal Finance Officers (IMFO) Conference (September 2011) <www.imfo.co.za/conference2011/Johann\%20Mettler.ppt>.

83 See 'Service-delivery Protesters Run Riot in Free State' Mail \& Guardian (23 August 2005) $<$ http://mg.co.za/article/2005-08-23-servicedelivery-protesters-run-riot-in-free-state>.

84 This is an organised street dance accompanied by singing as a sign of solidarity among protesters.

85 P Alexander 'Rebellion of the Poor: South Africa's Service Delivery Protests - A Preliminary Analysis' (2010) 37 Rewiew of South African Political Economy 25, 26.

86 See L Sinwell et al 'Service Delivery Protests: Findings from Quick Response Research on Four "Hotspots" - Piet Retief, Balfour, Thokoza, Diepsloot' (September 2009) Centre for Sociological Research, University of Johannesburg. 
By 2007, the protests were averaging 8.7 protests in a given month, moving to 9.8 in 2008, 19.1 in 2009 and had reached 16.33 by $2010 .^{87}$ The protests were against rising costs and declining access to such services as water, electricity and sanitation. ${ }^{88}$ Ironically, the protests came at a time when most municipalities had intensified efforts to implement policies that assured the poor access to free basic services including water and electricity. Susan Booysen has explained that even with the free services, the poor were plunged into debt traps when their consumption exceeded the free allowances, yet pressured for revenue, municipalities started implementing cut-offs. ${ }^{89}$ As a result, although a lot of money had been invested in extending services such as water and electricity to places that previously lacked these, many residents were still not enjoying the services because of disconnections arising from failure to pay. ${ }^{90}$

Most importantly, however, the service delivery crisis and the protests are indicators of the failure of local democracy. Elsewhere, I have illustrated the democracy deficit that has characterised local governance in South Africa, arising from the lack of meaningful participation of local communities in the decision-making processes. ${ }^{91}$ As Lilian Chenwi and Kate Tissington illustrate, the protests could be explained by poor communication and relationships of accountability with communities; weak community participation; and community alienation caused by not giving enough attention to 'bottom-up' planning and consultative processes. ${ }^{92}$ The manifestations of the alienation of the communities resulting from the absence of councillor representation has been summarised by Booysen:

South African local government from the mid-1990s on, and especially in the period 200006 , fell short of ... [the] ideal model ... reports of councillors effectively abandoning their communities prevailed in many parts of the country ... 'Absentee representation' ruled the day: Councillors were often neither resident in their communities nor were they available for consultation with their constituencies. ${ }^{93}$

In some circles, the service delivery protests, together with the xenophobic attacks that rocked the country in 2008, were viewed as an impact of more structured factors defining South African citizenship. It was reckoned that

87 See J Hirsh Community Protests in South Africa Trends, Analysis and Explanations' (2010) Community Law Centre, Local Government Working Paper Series 1.

88 Bond (note 78 above).

89 S Booysen 'With the Ballot and the Brick: The Politics of Attaining Service Delivery' (2007) 7 Progress in Development Studies 21, 24.

90 J Dugard 'Civic Action and Legal Mobilisation: The Phiri Water Meters Case' in R Berkhout \& J Handmaker (eds) Mobilising Social Justice in South Africa Perspectives from Researchers and Practitioners (2010) 178.

91 See C Mbazira 'Grootboom: A Paradigm of Individual Remedies versus Reasonable Programmes' (2011) 26 SAPL 60, 69.

92 L Chenwi \& K Tissington 'Engaging Meaningfully with Government on Socio-Economic Rights: A Focus on the Right to Housing' (March 2010) Socio-Economic Rights Project, Community Law Centre, University of the Western Cape 7.

93 Booysen (note 89 above) 23. See also C Bénit-Gbaffou 'Are Practices of Local Participation Sidelining the Institutional Participatory Channels? Reflections from Johannesburg' (2008) 66/67 Transformation Critical Perspectives on Southern Africa 1. 
there is a rapid process of class formation characterised by an emerging new elite, on the one hand, and on the other by an unemployed or precariously employed class. Additionally, dislocations in the transition from apartheid to democracy were generating fierce struggles over inclusion and exclusion both within the elite, between elites and subalterns, and within the subaltern classes themselves. ${ }^{94}$ However, be it as it may, poor performance on the service delivery front and the lack of meaningful engagement with constituencies remained a major factor. This is what Booysen has described as 'the fertile bases of dissatisfaction with social conditions and ... alienation from institutions of local government'.

Many of the protests started in a non-violent manner, with public meetings to discuss community problems and express dissatisfaction with local leaders, and in some cases characterised by years of appealing to local authorities to address the problems raised. ${ }^{96}$ In many of the meetings, the members would resolve to march to the local government offices and hand over memoranda detailing their dissatisfaction and calling for action. Unfortunately, again in many cases, the marches turned violent, sometimes after police provocation, although in others police swung into action when protesters became violent. ${ }^{97}$ In some cases, it was not easy to determine which side, police or the protesters, provoked violence. The police has however been accused of handling some of the protests in a brutal manner. ${ }^{98}$ One incident, captured on camera, and one which caused public outcry, was the death of Andries Tatane who was shot and beaten by police on 13 April 2011 at a protest in Ficksburg. Tatane was a community leader who had mobilised his community and worked tirelessly to ensure that the voices of his community were heard. In Voortrekker, a 29-yearold male was shot by the guard at the mayor's house. ${ }^{99}$ In Thandakukhanya, two males, aged 29 and 21 respectively were shot dead. ${ }^{100}$

Marcelle Dawson has examined the subject of policing protests from a wide perspective, by among others analysing legislative developments and the impact that these have had on the approach of the police when dealing with protesters. ${ }^{101}$ Dawson, for instance, illustrates how the 2009 amendment to Criminal Procedure Code, allowing the police to shoot at fleeing criminals, has influenced how the police handle protests. Also true is the fact that the

K von Holdt et al 'The Smoke that Calls: Insurgent Citizenship, Collective Violence and the Struggle for a Place in the New South Africa' (2011) The Centre for the Study of Violence and Reconciliation and Society, Work and Development Institute, University of the Witwatersrand 6.

95 Booysen (note 89 above) 24.

96 See Von Holdt et al (note 94 above) 33; and Sinwell et al (note 86 above).

97 See Bandeira \& Craig's description of the protests in Kungcatsh, Azania, Trouble and Ficksburg; M Bandeira \& C Higson-Smith 'Responding to the Smoke the Calls: Principles of Community Level Intervention for Collective Violence' (2011) The Centre for the Study of Violence and Reconciliation and Society, Work and Development Institute, University of the Witwatersrand.

98 See E Ferreira 'ICD: Rise in Police Abuse at Service Delivery Protests' Mail \& Guardian (14 June 2011)<http://mg.co.za/article/2011-06-14-icd-rise-in-police-abuse-at-service-delivery-protests>.

99 Von Holdt et al (note 94 above) 8.

100 Sinwell et al (note 86 above) 2 .

101 M Dawson 'Resistance and Repression: Policing Protest in Post-Apartheid South Africa' in Berkhout \& Handmaker (note 90 above) 101. 
police have not adequately been trained on crowd management, which has resulted in residents, who are exercising their freedom of assembly, being confronted by a police force encouraged to use maximum force in response to the high incidence of crime in the country. ${ }^{102}$

In many cases, the protests have attracted the attention of top government officials. In August 2009, for instance, President Zuma made a surprise visit to Siyathemba township in Balfour, Mpumalanga, an area that had been rocked by violent protests. ${ }^{103}$ Around the same time, the Minister of Human Settlements, Tokyo Sexwale, visited Diepsloot, announcing that he had come to understand the problems that the people face. ${ }^{104}$ The minister even spent a night in the shack of one of the residents, purportedly to enable him to better understand the suffering that shack dwellers experience. ${ }^{105}$ In some cases, the ANC reacted by firing local politicians, including mayors and councillors. ${ }^{106}$ The ANC, in these cases, struggled to impress the local communities that the problem does not lie with the ANC at the national level of government, but rather with inefficiencies of the leadership at the local level. ${ }^{107}$ According to Dugard, at least in the short-term, a local problem could be diffused and rising dissatisfaction over poverty and inequality could be moderated through the removal of specific councillors, while the central political economy stays intact and the ANC remains overwhelmingly popular. ${ }^{108}$

It should be noted that the evidence on the ground complicates the protests, which on the surface appear to be service delivery related, or triggered by service delivery failures; yet at the bottom, are deep and complex political issues. This could explain why, although the protests appear to be directed at the ANC, the party has remained strong and continues to win support at elections. Some of the protests have been fanned by dissent forces and factions within the ANC itself, sometimes led by ANC politicians who feel marginalised and their contribution to the ANC ignored. In some cases, leaders of the protests are ANC members who did not make it to the party's list, which would have given them access to political office. ${ }^{109}$ A study conducted by the Centre for the Study of Violence and Reconciliation (CSVR) and the Society, Work and Development Institute of the University of the Witwatersrand, shows that the organisers in some of the protests were officials of the local ANC branches,

102 Ibid 108

103 See 'Zuma Visit Pays Off for Balfour' Independent Online (7 September 2009) <http://www iol. co.za/news/south-africa/zuma-visit-pays-off-for-balfour-1.457699\#.UA05KrROCOU>.

104 See 'Sexwale Fails to Impress Cynical Residents' Mail \& Guardian (9 August 2009) <http:// mg.co.za/article/2009-08-10-sexwale-fails-to-impress-cynical-residents $>$.

105 See 'Rich Tokyo Spends Night Among Poor' Independent Online (4 August 2009) < http://www. iol.co.za/news/politics/rich-tokyo-spends-night-among-poor-1.453846\#.UA08TLROCOU>.

106 See for instance, A Moselakgomo 'Mayor is Fired after Mashishing Protests' Sowetan (3 September 2009) <http://www.sowetanlive.co.za/sowetan/archive/2009/09/03/mayor-is-fired -after-mashishing-protests>.

107 Dugard (note 78 above) 20.

108 Ibid 21.

109 M Hough 'Violent Protest at Local Government Level in South Africa: Revolutionary Potential?' (2008) 36 Scientia Militaria, SA J of Military Studies 1, 6. 
in many cases opposing ANC local government officials. ${ }^{110}$ In some cases, the local power shifts within the ANC had occurred, thereby sparking conflicts between the different local ANC official and raising questions of who goes in and who goes out of local government leadership. ${ }^{111}$ Unfortunately, the ANC appears to be glossing over these dynamics, and in some cases associating the protests to a 'third force' and most recently to 'criminal elements' that have infiltrated the communities with hidden agendas. ${ }^{12}$ The recent declaration by the ANC Youth League in the Western Cape that the league was going to incite protests and make the city ungovernable unless services are delivered complicates the situation even further. ${ }^{113}$ It turns the protests into a confrontation between the ANC and the opposition in areas controlled by the latter and raises questions on the role of communities in this regard.

\section{The Parallels and Divergences}

There are similarities but also differences between the context and protests in Uganda and South Africa. In the first place, in both countries, local governments have become the major vehicles for the provision of services. Yet, in both countries, these governments have not performed as effectively as expected, seen mainly in the failure of local democracy, which has resulted in a failure to effectively involve the local populations in the decision-making processes. ${ }^{114}$ This has been in addition to the unresponsiveness to the needs and demands of the people. The failure to nurture downward accountability and promote effective community participation could be explained by a range of factors, including incompetence and lack of skills on the part of the local institutions to mobilise and involve communities. There has been a general failure to appreciate, or, at the very least, put into practice, development models guided by a rights-based approach and based on community participation as a pre-requisite for economic and social development. At the same time, the patronising nature of local bureaucrats and politicians cannot be ruled out, and could, among others, be linked to the rising local predatory class. In spite of the fact that the courts have confirmed the duty on the state to ensure meaningful community participation as a constitutional imperative, ${ }^{115}$ in what in some cases the courts have described as 'meaningful engagement,' duty has not been fully discharged.

110 Von Holdt et al (note 94 above) 9.

111 Ibid 10 .

112 See 'Mangaung ANC "link" to New Wave of Protests' Business Day (7 August 2012).

113 M Williams 'We won’t Mess up Cape Town, ANC Says' Independent Online (7 August 2012) $<$ http://www.iol.co.za/news/politics/we-won-t-mess-up-cape-anc-says-1.1357774>.

114 See Doctors for Life International v Speaker of the National Assembly 2006 (6) SA 416 (CC); Matatiele Municipality v President of the Republic of South Africa 2007 (1) BCLR 47 (CC); and Merafong Demarcation Forum v President of the Republic of South Africa 2008 (5) SA 171 (CC).

115 See C Tapscott \& L Thompson 'Participatory Development in South Africa: Between Rhetoric and Practice' (2010) Paper presented to the 14th International Research Society for Public Management Conference, Berne Switzerland, 6-8 April.

116 See Residents of Joe Slovo Community, Western Cape v Thubelisha Homes 2010 (3) SA 454 (CC). 
As is the case in South Africa, local government in Uganda has created a predatory elite class represented by the local politicians and bureaucrats, thereby fomenting resentment in what appears to be a class struggle with protests as a tool. ${ }^{117}$ In Uganda, recent press reports for instance have indicated that municipal mayors and town council chairpersons were through their association, Urban Authorities Association of Uganda (UAAU) demanding a 400 per cent salary increment. ${ }^{118}$ In October 2011, through their association, the South African Local Government Association (SALGA), councillors demanded that they not only be paid by the national Treasury but their salaries and other emoluments be increased to match those paid to provincial politicians. $^{119}$

Although the broad policy motivation for decentralisation in both Uganda and South Africa appears to be the same: building local democracy and moving services close to the people in line with their needs, there are some differences in the legal frameworks of the two countries. In Uganda, the framework, as can be seen through its Constitution and Local Government Act, thinly defines service delivery as a central mandate of local government. Instead, as illustrated above, much of the law is dedicated to defining the administrative structures, offices and portfolios and the procedures of elections. In contrast, in South Africa, the framework puts services at the centre of local government by defining the service related rights of communities and the duties of local government in this regard.

The South African approach is bolstered by the constitutional framework which, unlike that of Uganda, expressly guarantees a number of socioeconomic rights such as housing, water, food and health care, as justiciable rights. ${ }^{120}$ Indeed, as illustrated by Jackie Dugard, in South Africa, some service delivery protests have been complimented by legal action in the form of constitutional petitions challenging the non-provision of services. ${ }^{121}$ In contrast, the Ugandan Constitution does not comprehensively protect socioeconomic rights as justiciable rights. The bulk of the rights are only protected as part of Directive Principles of state policy. Yet, although the Constitution creates opportunities for litigation of these rights through provisions allowing for public interest litigation, this has not generated as much litigation as one would have expected. ${ }^{122}$

What remains puzzling though is the fact that the differences in the legal frameworks notwithstanding, both countries have had unsatisfactory service

117 D Cammack et al 'Neopatrimonial Politics, Decentralisation and Local Government: Uganda and Malawi in 2006' (December 2007) Good Governance, Aid Modalities and Poverty Reduction Working Paper 2, 10.

118 'Municipal Mayors Want 400\% Salary Increment' New Vision (23 July 2012).

119 See M Pietersen 'Pay us More - Councillors' Independent Online (2 September 2011) <http:// www.iol co.za/news/politics/pay-us-more-councillors-1 1130133\#.UA1NO7ROCOU>.

120 See Constitution ss $26,27 \& 28$.

121 See Dugard (note 78 above).

122 See, C Mbazira 'Public Interest Litigation and Judicial Activism in Uganda: Improving the Enforcement of Economic, Social and Cultural Rights' (February 2009) Human Rights and Peace Centre Working Paper 24. 
delivery at the local government levels. One thing which stands out in South Africa are the contradictions in the legal framework, which promote service related rights and appear to accommodate the needs of the poor yet at the same time promote costs recovery. ${ }^{123}$ As illustrated by Dugard, the municipalities are under pressure to become financially self-sufficient and are in this respect not expected to have any deficits in their budgets, which has forced them to pursue a commercialised approach to service delivery. ${ }^{124}$ At the same time, the law as reflected in the Municipal Systems Act requires municipalities to contribute, together with other organs of state, to the progressive realisation of the fundamental rights contained in ss 24, 25, 26, 28 and 29 of the Constitution. ${ }^{125}$ These constitutional provisions guarantee access to a range of rights including housing, water, food and healthcare services.

In South Africa, in some cases, the protests have been pursued simultaneously with the use of the rights-based legal framework to protect and enforce the economic and social rights protected in the Constitution. This has created interplay between the legal processes and some of the protests, thereby establishing a dialectical relationship between these two as strategies. ${ }^{126}$ The dialectical relationship shows that litigation can be used as a tool for social mobilisation and building alliances, which, as was the case in Mazibuko $v$ City of Johannesburg, ${ }^{127}$ can result in gains even when the case is lost. In spite of losing the case in the Constitutional Court, the social mobilisation exerted pressure on the City to change its approach and be more responsive to the water needs of the poor. This approach is yet to be used in Uganda.

Additionally, both countries have experienced management deficiencies at the local government level. This is among others depicted in the financial management flaws, which both countries are experiencing. In South Africa, the recently released Auditor General's Report shows that only 13 (5 per cent) out of the 343 municipalities in the country had clean audits. This does not include any of the country's metros. ${ }^{128}$ None of the municipalities in such provinces as Gauteng, the Eastern Cape, Free State, Northern Cape and North West made it to the list of those with clean audits. It has been indicated that 45 per cent obtained unqualified audit reports. This figure tallies with the picture in Uganda, where in the financial year ending 30 June 2011, only 45 per cent of local governments obtained unqualified financial audits. ${ }^{129}$ This seemingly coincidental situation shows that local governments in both countries are performing at a level less than satisfactory as far as financial management is concerned, which is in turn affecting service delivery.

123 See Dugard (note 78 above) 1; and Bond (note 78 above).

124 Dugard (note 90 above) 77.

125 Municipal Systems Act s 4(2)(j).

126 Dugard (note 90 above) 85-94. See also J Dugard \& M Langford 'Art or Science? Synthesising Lessons from Public Interest Litigation and the Dangers of Legal Determinism' (2011) 27 SAJHR 39.

1272010 (4) SA 1 (CC).

128 See 'Only 13 Municipalities in the Whole Country have "Good Books"' Sowetan (23 July 2012).

129 See Auditor General's Report (note 38 above) 13. 
Unlike the case in Uganda, the protests in South Africa have been fairly well organised. South Africa has a history of organised civil disobedience and social mobilisation, which was used as a tool against the apartheid regime. ${ }^{130}$ Uganda does not enjoy a comparable experience. Attempts to build civil disobedience and social movements in Uganda were strangled during the time of colonial rule. ${ }^{131}$ In South Africa, some of the tactics used by the social movements characterised by well-organised community mobilisation have survived and been used by some of the protest leaders. As indicated above, many of the protests have been preceded with well-organised public meetings and writing of memoranda. One commonality though is that at the centre of the protest in both countries have been the unemployed youths, described by Dugard as the new generation of fighters. ${ }^{132}$ This does not however mean that the other members of the disgruntled communities are not part of the protests. What makes the youth visible is that they are usually the ones at the frontlines and engaging in running battles with the police.

In spite of the above differences in the levels of organisation, the increasing incidents of protests in both countries can be explained by the deep-seated discontent with the levels of service delivery and the ineffectiveness of the structures of participatory decision-making. ${ }^{133}$ In both countries, people have run out of patience waiting for the socio-economic transformation which liberation movements incarnated in the ruling parties, NRM and ANC, promised.

The range of services that have been the subject of protests also differ; in South Africa the major focus has been on housing, water and electricity. In contrast, in Uganda, in addition to electricity (mainly interruption and non-connection), the protests have focused on bad roads and poor healthcare services. It is not clear why 'poor health care services' has not been the subject of protests in South Africa, as there are serious deficiencies in the sector. This is a matter that merits separate investigation.

In both countries, the response of the police to the protests has been characterised with brutality and uncalled for violence. In the case of South Africa, the context in which police forces have brutalised protesters exercising their freedom of assembly has already been illustrated above. In Uganda, the police force is generally characterised by a number of irregularities. The police ranks as one of the most corrupt public institutions riddled with abuse of power, unprofessionalism, political impartiality and alienation from the community. ${ }^{134}$ Yet, the clandestine and unprofessional manner in which the

130 See, R Ballard 'Social Movements in Post-Apartheid South Africa: An Introduction' in P Jones $\&$ K Stokke (eds) Democratising Development The Politics of Socio-Economic Rights in South Africa (2005) 77.

131 See M Mamdani Politics and Class Formation in Uganda (1999).

132 Dugard (note 78 above) 13.

133 See Nyirinkindi (note 40 above); Sinwell et al (note 86 above); and Von Holdt et al (note 94 above).

134 See Common Wealth Human Rights Initiative The Police, The People, The Politics Police Accountability in Uganda (2006). See also ZZ Nagujja 'Human Rights and Structure of Police and Internal Security Forces in Uganda' (1997) 14 Third World Legal Studies 103. 
police force has handled public demonstrations is not different from South Africa. This is in the main attributable to inadequate training and negligence on the part of members of the force. ${ }^{135}$

The exercise of police powers in policing protests needs to be understood against the human rights implications of protest action. Police need to understand that protest is a right which needs to be protected. It has been argued that public protest is part of freedom of expression, and used by persons to ensure that free speech reaches the targeted audiences. ${ }^{136}$ By the protests, such groups 'are able to gain access to the media through publicity and to persuade members of their immediate audience to sympathise with their stance'. ${ }^{137}$ As early as the 1960s, one scholar described protests as a new moral-political force being used to challenge political alienation and find fulcrum for political leverage, and that protests should be viewed as 'obedience' and not 'disobedience'. ${ }^{138}$ This is because protests are an act in the pattern of democratic tradition and part of the freedom of expression. ${ }^{139}$ Harrop Freeman traced the technique of protests to Mahatma Ghandi, who used it as a tool of effecting change within the law when the law's normal procedures were inadequate or were held captive by anti-legal forces. ${ }^{140}$ Ghandi's philosophy of protest, satyagrah, was influenced by Hindu philosophy that the most effective sacrifice was self-sacrifice and suffering, while refusing to injure others. ${ }^{141}$ Freeman uses the term 'civil disobedience' as one of the forms of protests, and describes its characteristics to include: (a) it is an intentional chosen act not occasioned by accident; (b) it is used to call attention to injustice and to change conditions; (c) it is non-violent, at least in origin; (d) it is a form of communication; (e) it is used by those who are otherwise barred from exerting power; and (f) may be legal or illegal. ${ }^{142}$

One shortcoming with Freeman's article though is that it does not expressly address the question of whether or not violent protest is justified. He defines 'violence' as the wilful application of physical force in such a way that it is physically injurious to the person or group subjected to the force. ${ }^{143}$

It has been indicated that the means used by the protesters will only be justified by demands of democratic expression, but only as long as they are not outweighed by the threat posed by the action. ${ }^{144}$ According to Helen Fenwick, even if a group does not seek to persuade others, by the group's actions 'the democratic process may be said to have been circumvented rather than

135 J Oloka-Onyango 'Taking Orders from Above: Police Powers, Politics and Democratic Governance in Post-Movement Uganda' (2011) HURIPEC Working Paper 31, 24.

136 H Fenwick 'The Right to Protest, the Human Rights Act and the Margin of Appreciation' (1999) 62 MLR 491, 492.

137 Ibid 493.

138 HA Freeman 'The Right to Protest and Civil Disobedience' (1966) 41 ILJ 228.

139 Ibid.

140 Ibid.

141 Ibid 232.

142 Ibid 231-2.

143 Ibid 229.

144 Fenwick (note 136 above) 494. 
underpinned'. ${ }^{145}$ Although the right to protest has been acknowledged, the use of violent repertoires has been castigated. ${ }^{146}$ This is the same approach which has been adopted by international human rights law as it guarantees only the 'right to peaceful assembly'. 147

The United Nations has adopted international standards that among others regulate policing of assemblies. These are contained in the United Nations Basic Principles on the Use of Force and Firearms by Law Enforcement Officials. ${ }^{148}$ The principles provide that in the dispersal of assemblies that are unlawful but non-violent, law enforcement officials shall avoid the use of force or, where that is not practicable, shall restrict such force to the minimum extent necessary. ${ }^{149}$ In the dispersal of violent assemblies, law enforcement officials are required to use firearms only when less dangerous means are not practicable and only to the minimum extent necessary. Yet, law enforcement officials shall not use firearms in such cases, except under the conditions stipulated in principle 9. ${ }^{150}$ Principle 9 provides that officials shall not use firearms against persons except in self-defence or defence of others against the imminent threat of death or serious injury, to prevent the perpetration of a particularly serious crime involving grave threat to life, to arrest a person presenting such a danger and resisting their authority, or to prevent his or her escape, and only when less extreme means are insufficient to achieve these objectives. That, in any event, intentional lethal use of firearms may only be made when strictly unavoidable in order to protect life.

\section{CONCLUSION}

Although decentralisation has been embraced by both South Africa and Uganda as a vehicle for service delivery at the local levels, effective service delivery has not been realised at these levels. In both countries, the local governments are characterised by poor management, maladministration and abuse of finances. From the point of view of local democracy, one of the incentives of decentralisation, there has largely been a failure of democracy at this level. The ability of people to articulate their own needs, directly influence policies and actively participate in the processes through which these needs

145 Ibid.

146 D della Porta 'Protest, Protesters, and Protest Policing: Public Discourses in Italy and Germany from the 1960s to the 1980s' in M Giugni, D McAdam \& C Tilly (eds) How Social Movements Matter (1999) 66, 81.

147 See art 20 Universal Declaration of Human Rights (1948); art 21 of the International Covenant on Civil and Political Rights (1966); and art 11 of the European Convention on Human Rights (1950). On its part though, the African Charter on Human and Peoples Rights subjects the exercise of the right to free assembly 'only to necessary restrictions provided for by law in particular those enacted in the interest of national security, the safety, health, ethics and rights and freedoms of others' (see art 11).

148 Adopted by the Eighth United Nations Congress on the Prevention of Crime and the Treatment of Offenders, Havana, Cuba (27 August to 7 September 1990).

149 Principle 13.

150 Principle 14. 
can be satisfied has largely failed. ${ }^{151}$ Where participation has occurred, it has not been meaningful, and on some occasions the processes have been hijacked by politicians and bureaucrats, who are part of the emerging predatory local elite.

While the contexts in the two countries may differ, both countries have experienced a wave of service delivery protests in which people have risen up against their local governments demanding better services. In both countries, the protests have been caused not only by frustration about services but also by the failure of the local governments to take into account the voices of the local communities in decision-making processes. The protests also arise from the loss of confidence in the governments because of the failure to meet the needs of the people, in spite of promises to do so as part of transformation. Nonetheless, the protests in the two countries have differed in magnitude and levels of organisation. The South African protests have taken advantage of a history of social mobilisation to be massive, organised and in some cases drawn-out.

In both countries, there is an urgent need to build the civic competence of the local communities and to ensure that there are operational and effective structures for civic participation. To borrow from Laura Nyrikindi, it is necessary for local governments to develop awareness and information dissemination mechanisms in user-friendly forms and avail these regularly in order to build the capacity of the local communities to participate meaningfully in the service decision-making processes. ${ }^{152}$ In the same respect, local governments should address the structural bottlenecks that constrain meaningful participation in decision-making and go beyond the structured statutory procedures. ${ }^{153}$ 